\title{
The Effectiveness of Implementing PQ4R Models on Improving Students' Reading Comprehension
}

\author{
Prima Rahmadia ${ }^{1 *}$, Sitti Fatimah ${ }^{2 *}$ \\ ${ }^{12}$ Universitas Negeri Padang, Padang, West Sumatra, Indonesia \\ "Corresponding author. Email: primarahmadia@gmail.com
}

\begin{abstract}
The Preview, Question, Read, Reflect, Recite and Review (PQ4R) strategy was implemented by utilizing a quasiexperimental research design in order to find out whether the strategy was effective to improve students' reading comprehension. Using a cluster random sampling technique, two groups of Grade 11 students from a Muhammadiyah Senior High School (SHS) in Padang were recruited as the experimental (Class A) and control (Class B) groups. A reading comprehension test was administered only at the end of the implementation to see the effectiveness of implementing the PQ4R strategy. The results show the significance value 0.042 at stage 0.05 . It approach that the price changed into decrease than significance alpha 0.05 at level of significant $5 \%$. These prove that the $\mathrm{H} 0$ saying PQ4R strategy does not improve students' reading comprehension is rejected, however Ha saying PQ4R strategy improves students' reading comprehension is accepted. Thus, there is a significant effect of implementing PQ4R strategy on the improvement of students' reading comprehension.
\end{abstract}

Keywords: $P Q 4 R$ strategy, reading comprehension

\section{INTRODUCTION}

Many Indonesian high school students still encounter a problem in understanding English reading texts. One of the outstanding causes is their lack of reading interest. A study conducted by Central Connecticut State University in March 2016 [1] shows the evidence. Indonesia was ranked the 60th out of the 61 countries regarding reading interest. A recent and closer observation at a Muhammadiyah Senior High School in Padang reveals more specific factors of why many students have problems in comprehending and analyzing textual content. First, the students fail to understand a passage because of their unfamiliarity with a lot of vocabulary found in the texts. Second, the teacher fails to adopt appropriate strategy in teaching reading. This second factor is considered to be a crucial one to determine students' success in comprehending the reading passages.

The instructor desires an awesome method to make college students recognize what they study and revel in with inside the gaining knowledge of process. PQ4R is an awesome method, which has the coolest idea to educate the scholars analyzing comprehension [3]. In every step of the PQ4R method, the scholars can without problems recognize the textual content. Before at once analyzing the textual content, first off the scholars preview the textual content with the aid of using searching on the identify and heading of the textual content, so one can recollect their previous knowledge.

In conclusion, the teacher applies an effective strategy to make students comprehend the text. The reader also must know how to improve the students' motivation in the reading activity. Actually, there are many strategies that can be used in teaching in order to make students interested to read. Young children are developing as readers when they are able to understand, interpret and critique what they read [4]. The strategy is Tried-and-Try Teaching Strategy, Cloze Strategy, Explicit Strategy and PQ4R Strategy. Furthermore, $\mathrm{PQ} 4 \mathrm{R}$ is the acronym for preview, question, read, reflect, recite and review[3]. The strategy stimulates students to actively engage the subject matter".

Based on the previous studies, research related to PQ4R attracts many educators to research some kinds of reading comprehension. PQ4R improved students' reading comprehension and the conclusion $P Q 4 R$ is an effective strategy in teaching reading[5]. While PQ4R to improve teaching and learning reading narrative text[6]. Based on their research, the use of PQ4R can improve the students' reading comprehension, and PQ4R strategy has increased students reading skill and it proves that PQ4R strategy helps the students understand the material easily. It is the main key to success in learning reading. The good strategy can also help the students' understand the reading text. Thus, the teachers need to find out an effective strategy to help students in comprehending the text easily. 
Furthermore, there are much research related to the use of PQ4R, Fatuni'mah and Rodli conducted their research focusing on using $\mathrm{PQ} 4 \mathrm{R}$ in teaching reading narrative text. PQ4R Strategy can be used as opportunity approach in coaching analyzing specially in coaching analyzing textual content type, just so the scholars can understand textual content text without difficulty and extra inquisitive about analyzing activity[7]. PQ4R strategy and its use as an alternative to improve students' reading comprehension achievement[8]. Both of these studies show that the score of the Experimental elegance taught with the aid of using the usage of PQ4R was higher than The manipulate magnificence taught without a PQ4R.

Among those several previous studies, PQ4R also catch the attention of many researchers in some countries. The results indicated that PQ4R strategy greatly improved the scholastic achievement of students. In the light of results, directions for future research has been given conducted the research related to the use of PQ4R strategy in the teaching and learning process [9].

In Indonesia, the use of PQ4R in senior high school level students has been done by some researchers. First PQ4R strategy highly improved students' reading comprehension of narrative text and the data from questionnaire and interview showed that students gave positive responses toward PQ4R strategy[10]. Second, also conducted research related to the use of PQ4R, she research findings show that PQ4RTPS learning strategy is significantly more potential in empowering students' metacognitive skills compared to the other learning[11]. PQ4R-TPS learning strategy needs to be implemented, accustomed to, and continuously trained to the students in order to improve their metacognitive skills. The last, It may be concluded that the student's analyzing comprehension after being taught using PQ4R technique is better than before being taught using the technique[12]. As a result PQ4R is believed to be effective towards the student's reading comprehension. Finally, PQ4R technique can be used as a technique to teach reading comprehension for the first grade of senior high school students.

In line with the issues formerly described, the trainer wishes a very good approach to make college students apprehend what they study and revel in in mastering process. PQ4R is an first-rate approach, which has a true idea to educate the scholars studying comprehension. In every step of PQ4R approach, the scholars can effort lessly realize the textual content. Before without delay studying the textual content, first of all the scholars preview the textual content with the aid of using searching on the name and heading of the textual content, with a view to consider their previous knowledge. Then, they want to shape predicting questions in order to lead them to smooth to discover the thoughts with inside the textual content. Then, in addition they want to read the textual content absolutely to discover the solutions for the questions before. This approach additionally presents reflect in studying a textual content, due to the fact they want to memorize what they recognize approximately the textual content with the aid of using summarizing the textual content. And then, they want to recite it aloud. And finally, on the cease of this step is review. They want to check to ensure that each one questions had been replied and the thoughts with inside the textual content had been memorized

Then, they want to shape predicting questions with a view to lead them to smooth to discover the thoughts with inside the textual content. Then, in addition they want to study the textual content absolutely to discover the solutions to the questions before. This approach additionally presents mirrored image studying a textual content, due to the fact they want to memorize what they recognize approximately the textual content with the aid of using summarizing the textual content,and then, they want to recite it aloud. Finally, the last step is review. They want to check to ensure that each one questions had been replied and the thoughts with inside the textual content had been memorized.

Through the PQ4R method, the students' reading process is more focused and can overcome students' difficulties related to reading comprehension. Based on this background, the researcher will examine the improvement of reading comprehension skills by using the PQ4R strategy strategy.

Despite some studies have been conducted related to improving students' reading comprehension by using PQ4R strategy in some countries and Indonesia. Now, there is a lack of studies focusing on implementation iveness of PQ4R strategy in SMA at XI IPS students. This research mainly involved one school and concerned to see implementation of PQ4R strategy in students' reading comprehension.

\section{METHODS}

The type of research used is quasi-experiment using post-test only control design. Population is the group of interest to the researcher, the group to which this research want the result of the study to be generalized so that population is total number of the students of the research[13]. In this research, the population is the XI IPS students at SMA Muhammadiyah 3 Padang. They are 116 students which consist of eight classes of XI IPS at SMA Muhammadiyah 3 Padang that registered in 2019/2020.

The sampling technique used in this study was cluster random sampling. Cluster random sampling is a 
technique of selecting a sample from small groups of units. In this research, four classes are chosen to be the sample candidate of this research. The steps for selecting a sample using the cluster random sampling technique are as follows (a) Collecting the last test scores for Class XI IPS SMA Muhammadiyah 3 (b) The normality test using the Lilieffors test and the data obtained for the values of the four classes are normally distributed, it can be seen in the table below.

Table 1: Sample Class Normality Results

\begin{tabular}{|c|c|c|c|c|}
\hline No & Kelas & sig & $\boldsymbol{\alpha}$ & Keterangan \\
\hline 1 & XI IPS 1 & 0,18 & 0,05 & Normal \\
\hline 2 & XI IPS 2 & 0,25 & 0,05 & Normal \\
\hline 3 & XI IPS 3 & 0,15 & 0,05 & Normal \\
\hline 4 & XI IPS 4 & 0,21 & 0,05 & Normal \\
\hline
\end{tabular}

From the table above, because the four classes have a significant value > alpha (0.05), it can be concluded that the four classes are normally distributed. (c) Perform homogeneity test to find out whether the population has the same variance or not. In this case, the researcher used the Barlett test. It became determined that the significance value of students' analyzing comprehension test both classes, it can be seen the importance fee is 0.206 at degree 0.05 . It approach that the fee changed into better than significance alpha 0.05 . It means that the data are homogeneous (d) Since only two classes were selected, then, after conducting the normality test and homogeneity test, the sample was selected using cluster random sampling technique, the lottery. The first lottery selected as the experimental class and the second lottery as the control class. Then obtained class XI IPS 1 as the experimental class and class XI IPS 3 as the control class.

The instruments in this study were the reading comprehension test and the questionnaire of reading motivation. Before give reading comprehension test the determined of validity, the researcher will use expert validation and reliability of the text by giving test class. Questionnaire of Reading Motivation whether the questionnaire is valid and reliable. The prerequisite test includes the normality test using the KolmogotovSmirnov method using SPSS and the homogeneity test using Levene method using SPSS. It can be concluded that the sample comes from a population that is normally distributed and has homogeneous variance. The hypothesis of this study used t-test formula.

\section{FINDINGS AND DISCUSSION}

In this research, the data of students' reading comprehension were taken from post check in each experimental magnificence and manipulate magnificence. The information of post-test was analyzed by using SPSS 20 for Windows. Furthermore, before testing the hypothesis, normality and homogeneity was tested with significance alpha 0.05.Then, the hypothesis was tested using independent sample t-test formula.

The normality test is used to find out whether the students' reading comprehension for the two classes, namely the experimental class and the control class, comes from a normally distributed sample. The normality test uses the Kolmogorov-Smirnov method using SPSS. The criterion for normality is if the significance value (sig) is more than $\alpha(0.05)$ the data is normally distributed. Based on the the result of normality testing of students' reading comprehension test in experimental and control class. In experimental class, it can be seen The importance cost is 0.242 at degree 0.05 . It approach that the cost changed into higher than 0.05 and it is able to be concluded that the records in experimental magnificence changed into typically distributed. Furthermore, on top of things magnificence it is able to be visible the the importance cost is 0.200 at degree 0.05 . It approach that the cost changed into better than 0.05 and it is able to be concluded that the records on top of things magnificence changed into typically distributed.

The homogeneity test used in this study for groups of students with the PQ4R strategy and conventional learning models. Homogeneity test used in this study is Lavene statistic using SPSS for groups of students with the PQ4R strategy and conventional. The criterion for homogeneity is if the significance value (sig) is more than $\alpha(0.05)$, the data has the same variance. Based on the result, It become observed that the importance cost of students' analyzing comprehension take a look at each classes, it is able to be visible the the importance cost is 0.308 at degree 0.05. It manner that the cost become better than significance alpha 0.05 . It means that the data are homogeneous.

In addition, $\mathrm{Ha}$ is accepted if significance value is lower than significance alpha 0.05 and $\mathrm{Ha}$ is rejected if significance value is higher than significance alpha 0.05 . The result of the data analysis of reading comprehension test by using t-test in both experimental and control class. Based on the result, it can be seen the the significance value is 0.042 at level 0.05 . It means that importance fee is 0.042 at degree 0.05 . It method that the fee became decrease than importance alpha 0.05at degree of enormous 5\%. It method that the null hypothesis (Ho) saying "PQ4R strategy does not produces higher achievement on reading comprehension on the students' at SMA Muhammadiyah 3 Padang is rejected and the alternative hypothesis (Ha) saying PQ4R strategy does produces higher achievement on 
reading comprehension on the students' at SMA Muhammadiyah 3 Padang is accepted". So, it can be concluded that there is a significant effect of PQ4R strategy on students' reading comprehension.

From the table above we can see based on the value (sig). For testing hypothesis 1 , based on the SPSS output on the PQ4R strategy variable, it was it means that the PQ4R method has a substantial impact on students' analyzing comprehension.It means that there is an influence on the reading comprehension of students who are given the PQ4R strategy and the conventional learning model. In the experimental class is given PQ4R strategy. PQ4R strategy consists of Preview, Question, Read, Reflect, Recite, and Review. Based on the researcher got from the treatment this strategy can make students active in learning process, proved with class treatment that use PQ4R method by researcher at SMA Muhammadiyah 3 Padang.

By implementing PQ4R Strategy, the students can be more active in learning process in the class. They also will be easy to understand the material. Hopefully, the teachers are able to apply this strategy, because it is appropriate and helpful to increase the students' achievement and make students get good mark. Then, the finding of this research is relevant with other previous findings conducted which found the use PQ4R method can be used as opportunity method in coaching studying mainly in coaching studying textual content type, just so the scholars can realize textual content text without problems and extra in terested by studying activity in the control class is given conventional learning model[7]. Conventional learning model is a learning model commonly used by previous teachers, namely the lecture method so that the students are not interested in learning process because they do not concentrate about the lesson that is given by teacher so that the students are difficult to develop their ideas in comprehend the text. That is what makes the difference between the reading comprehension of students who are given the PQ4R learning model and the conventional learning model. PQ4R strategy and its use as an alternative to improve students' reading comprehension achievement[8]. The experimental elegance taught with the aid of using the usage of PQ4R and the manipulate magnificence taught without a PQ4R.

This is in line with the research was being the results state that From the implementation iveness of the learning model that is applied to the design of experimental studies with control class it may be concluded that reading learning model based on PQ4R metacognitive strategies in junior high school students[2]. In Punjab (Pakistan), the results indicated that PQ4R study strategy greatly improved the scholastic achievement of students[9]. In the light of results, directions for future research has been given conducted the research related to the use of PQ4R strategy in the teaching and learning process.

\section{CONCLUSION}

After the implementation, PQ4R strategy is beneficial for the students' reading comprehension ability. It can be inferred from students' achievement in reading activity in the classroom. Then, the statistical data also showed that students who were taught by using PQ4R strategy have better reading comprehension score than those who were taught by using conventional teaching. Hence, PQ4R strategy is valuable to be applied during the learning process since it can affect the students' reading comprehension significantly.

The result of this research has some implications on English language teaching, especially in teaching reading.Teaching reading through $\mathrm{PQ} 4 \mathrm{R}$ strategy affects students' reading ability significantly. It is proven that PQ4R strategy is better than conventional teaching. As a technique in teaching, PQ4R strategy is effective, especially in teaching reading. PQ4R strategy as one of the teaching techniques promoted communicative language teaching and very suitable to be applied in learning reading The PQ4R method is one of the best reading methods for reading comprehension. The PQ4R method is an effective strategy to develop understanding of the materials, with the aim that students can understand the content. Besides PQ4R is an first-rate strategy, which has excellent idea to educate the scholars studying comprehension. In every step of PQ4R strategy, the scholars can without problems understand the text.

\section{REFERENCES}

[1] S. Somadayo, Strategi dan Teknik Pembelajaran Membaca. Yogyakarta: Grtaha Ilmu, 2011.

[2] N. Samniah, "Kemampuan Memahami Isi Bacaan Siswa Kelas VIIMTs Swasta Labibia,' J. Humanika, vol. 16, no. 1, pp. 1-16, 2016.

[3] A. Suprijono, Cooperative Learning: Teori \& Aplikasi Paikem. Yogyakarta: Pustaka Pelajar, 2010.

[4] D. Lapp and D. Fisher, Essensial Readings on Comprehension. The International Reading Association. Chicago: International Reading Association, 2009.

[5] D. E. Martina, "Implementation of Using PQ4R (Preview, Question, Read, Reflect, Recite, Review) Strategy on EFL Students' Reading Comprehension Achievement," Res. English Educ. J., vol. 3, no. 1, pp. 17-24, 2018.

[6] J. I. Rahajeng, "Teaching And Learning Reading Narrative Text By Using Pq4r Strategy 
At The Second Semester Of The Eighth Grade Of Smp Muhammadiyah 1 Kalianda In The Academic Year Of 2017/2018," UIN Raden Intan Lampung, 2018.

[7] A. Fatuni'mah, "Teaching reading narrative text through PQ4R (Preview, Question, Read, Reflect, Recite and Review) strategy: an experimental research at the Ninth Grade of SMP Ma'arif NU 02 Jatinegara in the academic year of 2015/2016," Universitas Islam Negeri Walisongo Semarang, 2015.

[8] M. Rodli, "Improving the Reading Comprehension of the Tenth Year Students of MAN Mojokerto Using PQ4R Strategy," Universitas Negeri Malang, 2020.

[9] R. Bibi and M. H. Arif, "Effect of PQ4R Study Strategy in Scholastic Achievement of Secondary School Students in Punjab (Pakistan)," Lang. India, vol. 11, no. 12, 2011.

[10] M. Bayu, "The Use of PQ4R in Teaching Students'reading Comprehension of Narrative Text (Doctoral dissertation, Universitas Pendidikan Indonesia)," Universitas Pendidikan Indonesia, 2013.

[11] H. Setiawati and A. D. Corebima, "Improving students' metacognitive skills through science learning by integrating PQ4R and TPS strategies at a senior high school in Parepare, Indonesia," J. Turkish Sci. Educ., vol. 15, no. 2, pp. 95-106, 2018.

[12] H. S. Tyastuti, "Implementationiveness of Using PQ4R Strategy in Teaching Student's Reading Comprehension of Narrative Text at the First Grade of Senior High School.," IAIN Tulungagung, 2019.

[13] P. Airasian and L. R. Gay, Gay, \& Airisian. (2000). Educational Research Competences for Analysis and Application. New Jersey: Prentice Hall Inc, 2000. 